Institute of
Medicinal Plants

Review Article

\title{
Clinical efficacy of Silybum marianum seed extract in treatment of type 2 diabetes mellitus and non-alcoholic fatty liver disease: a narrative review
}

\author{
Sayed Mohammad Mohammadi' ${ }^{1}$, Saeed Kianbakht ${ }^{2}$, Shamsali Rezazadeh ${ }^{2}$, Mojtaba Ziaee ${ }^{3}$, \\ Hasan Fallah Huseini ${ }^{2}$,* \\ ${ }^{1}$ Department of Internal Medicine, Shahid Sadoughi University of Medical Science, Yazd, Iran \\ ${ }^{2}$ Medicinal Plants Research Center, Institute of Medicinal Plants, ACECR, Karaj, Iran \\ ${ }^{3}$ Cardiovascular Research Center, Tabriz University of Medical Sciences, Tabriz, Iran
}

\begin{tabular}{|c|c|}
\hline ARTICLE INFO & ABSTRACT \\
\hline $\begin{array}{l}\text { Keywords: } \\
\text { Clinical trial } \\
\text { Diabetes mellitus } \\
\text { Fatty liver } \\
\text { Silymarin }\end{array}$ & $\begin{array}{l}\text { Background: Several clinical studies have been undertaken to investigate the } \\
\text { potential therapeutic effects of Silybum marianum (S. marianum) seed extract } \\
\text { (silymarin) in Type } 2 \text { diabetes mellitus (T2DM) and non-alcoholic fatty liver } \\
\text { disease (NAFLD). Objective: We performed the present narrative review to } \\
\text { evaluate the efficacy of silymarin supplement for treatment of T2DM and } \\
\text { NAFLD. Methods: Electronic databases PubMed, Science Direct, Scopus, } \\
\text { Google and Google Scholar were surveyed for the English and non-English } \\
\text { human clinical trial papers published concerning the effects of silymarin on } \\
\text { T2DM and NAFLD from January } 2010 \text { to April } 2018 \text {. Results: Sixteen articles } \\
\text { regarding silymarin effects on T2DM and NAFLD in clinical studies have been } \\
\text { included in this review. The anti-diabetic effect of silymarin was reported in four } \\
\text { clinical trials in single formula and in one trial in combination with nettle and } \\
\text { boswellia gum resin. The efficacy of silymarin or silybin has been reported in the } \\
\text { treatment of NAFLD in eleven clinical trials as single formula or in combination } \\
\text { with phosphatidylcholine, simvastatin and vitamin E. Conclusion: Silymarin } \\
\text { appears to be effective as an adjuvant with the standard therapy in the treatment } \\
\text { of T2DM and NAFLD. }\end{array}$ \\
\hline
\end{tabular}

\section{Introduction}

Type 2 diabetes mellitus (T2DM) which is one of the fast growing health problems and NAFLD as the leading cause of liver disease provide considerable challenge for the patients and healthcare systems all over the world [1-2]. Type 2 diabetes (T2DM) and the non-alcoholic fatty liver disease (NAFLD) are both chronic metabolic disorders which frequently co-exist [3]. They can act synergistically in order to drive

Abbreviations: NAFLD, non-alcoholic fatty liver disease; T2DM, type 2 diabetes mellitus; HbA1c, glycated hemoglobin; LDL, low-density lipoproteins; hs-CRP, high-sensitivity C-reactive protein

* Corresponding author: $\underline{\text { h.fallah@acecr.ac.ir }}$

doi: 10.29252/jmp.1.73.12

Received 23 October 2018; Received in revised form 10 February 2019; Accepted: 10 March 2019

(C) 2020. Open access. This article is distributed under the terms of the Creative Commons Attribution-NonCommercial 4.0 International License (https://creativecommons.org/licenses/by-nc/4.0/) 
an adverse effect related to both diseases such as macro- and micro- vascular complications and the risk of more severe NAFLD, including cirrhosis, hepatocellular carcinoma and ultimately death [4-5]. T2DM and NAFLD too, have some common risk factors such as obesity and physical inactivity [6-7]. Despite the administration of modern drug regimens, therapeutic treatment of NAFLD is currently limited and diabetes control is not achieved satisfactorily which has caused an interest in complementary and alternative medicine [8-11]. Interestingly, the therapeutic effects of the medicinal plant $S$. marianum have been reported in both T2DM and NAFLD [12-13]. S. marianum or milk thistle, an edible plant, has red or purple petals, pale green leaves with white veins and is a native of the Mediterranean region, however, it is grown all across the world [14-15]. $S$. marianum has been known as a medicinal plant whose therapeutic history dates back to ancient eras and it was once used for the treatment of some hepatic disorders such as jaundice and fatty liver disease [16]. Recent studies have demonstrated that $S$. marianum seed extract (silymarin) can reduce the fasting and postprandial plasma glucose levels as well as HbA1c in diabetic patients when used in conjunction with oral anti-diabetic therapy [17]. Some reports indicated anti-inflammatory, antioxidative, anti-fibrogenic and hypolipidemic effects of silymarin which may induce some beneficial therapeutic effects in the treatment of chronic liver diseases [18-20].

This review aims to evaluate the clinical efficacy of silymarin in the treatment of T2DM and NAFLD. Thus, all the available clinical trial papers published from January 2010 to April 2018, regarding the effects of silymarin in the treatment or the prevention of T2DM and

Journal of Medicinal Plants
NAFLD have been investigated, and included in this survey.

\section{Methods}

Electronic databases, PubMed, Science Direct, Scopus, ProQuest, Google Scholar, from January 2010 to April 2018, using the terms milk thistle, silybum marianum, silybin, silymarin, medicinal plant, diabetes mellitus, glycemic control, liver disease, fatty liver, non-alcoholic fatty liver disease and clinical trial have been searched as keywords.

\subsection{Study selection}

All of the human studies with the key outcome effects on blood glucose and HbA1c for T2DM patients and hepatic enzymes, serum lipids, fatty liver disease and anti-inflammatory effect for NAFLD have been included. The experimental animal, in vitro and in vivo studies, review articles, letters to the editor as well as the unpublished data were excluded.

\section{Results}

\subsection{Silybum marianum botany and habitat}

S. marianum with common name milk thistle belongs to the genus Cardus, and is possibly endemic to southeastern England coastal areas now widely traveled outside its habitat including North America, Iran, Australia and New Zealand, where it is considered an invasive weed [14]. In Iran, this plant grows naturally in GonbadKavoos between Gorgan and Node Kelardasht, Haraz valley, Moghan Plain, Molasani in Ahvaz, Hamidieh, Ramhormoz, Izeh, and Kazerun [15]. The plant grows upright and is usually $90-180 \mathrm{~cm}$ tall, the stems are branched, quite thick, hairless or sparsely covered with cottony or downy hairs. The leaves are mottled green, shiny and have a distinctive variegated appearance. The flowers are large purplish flower-heads at the tips of the 
branches and usually appear in spring and early summer. The seeds are 5-8 mm long and about 3 $\mathrm{mm}$ wide and yellowish-brown in color with black streaks that give them a mottled appearance [15].

S. marianum has been used for centuries in traditional herbal medicines to treat pancreatic inflammation, jaundice, gallbladder stones and other liver disorders. [16-20]. S. marianum seeds are currently used for some liver diseases approved by the Food and Drug Administration of Germany for some digestive disorders, hepatic poisoning and cirrhosis [21].

\subsection{Chemical constituents}

S. marianum seed extract contains some 4-6\% silymarin. The extract consists of about $65-80 \%$ silymarin and $20-35 \%$ fatty acids including linoleic acid. Silymarin contains a family of natural compounds called flavonolignans such as silybin A, silybin B, silydianin, isosilybin A, isosilybin B, silychristin (Fig. 1) and the other compounds in smaller concentrations [22-24]. However, silybin is the major bioactive component of silymarin with strong antioxidant properties (Fig. 2).

\subsection{Anti-diabetic clinical trials}

Seven randomized double-blinded, placebocontrolled studies of silymarin as a single therapy and one instance in combination with other herbs in the treatment of diabetic patients were identified.

In the first study [25], a total number of 51 male and female type II diabetic patients were included. All participants were aged between 40 and 65 . The patients had a fasting blood glucose level of less than $250 \mathrm{mg} / \mathrm{dL}$, the duration of diabetes lasted more than 2 years, and their diabetes was not controlled by oral agents as well as diet. The exclusion criteria were insulin therapy, cardiovascular diseases, infectious diseases, pregnancy and breastfeeding. The patients were randomly assigned to two groups of 25 using a balanced randomization method. Silymarin $(200 \mathrm{mg})$ or placebo tablets were administered three times a day for 4 months and conventional oral hypoglycemic agents (metformin and glibenclamide) treatment continued for the two groups. The results indicated that silymarin treatment significantly lowered the HbA1c and the fasting blood glucose levels in diabetic patients at the end of the study. Accordingly, it led to meaningful decrease of total cholesterol, LDL, triglyceride, liver enzyme levels.

In the second study [26], a total number of 60 male and female patients with type II diabetes were recruited. All participants were aged between 40 and 65 . One group $(n=30)$ received $750 \mathrm{mg}$ silymarin in three divided doses while the control group $(n=30)$ received placebo. The oral hypoglycemic standard therapy was continued for the two groups during the study. The study lasted 4 months. The results showed a significant decrease in fasting blood glucose levels from $155 \pm 46 \mathrm{mg} / \mathrm{dl}$ to $133 \pm 39 \mathrm{mg} / \mathrm{dl}$ $(\mathrm{P}=0.001)$ as well as $\mathrm{HbA1c}$ levels from $7.82 \pm 2.01$ to $6.78 \pm 1.05 \quad(\mathrm{P}=0.001)$ in the silymarin group. There was also a significant decrease in aspartate aminotransferase $(\mathrm{P}=0.008)$ and alanine aminotransferase $(\mathrm{P}=0.0001)$ levels in the silymarin treated group.

In the third study [27], the effects of silymarin on glycemic control in type II diabetes patients who were intended to be on insulin therapy ,were investigated in a 2-month randomized placebo controlled clinical trial study. In this study, one group ( $\mathrm{n}=30$ ) received $200 \mathrm{mg}$ silymarin tablets three times a day in addition to standard therapy, 
<smiles>COc1cc([C@H]2Oc3cc([C@H]4CC(=O)c5c(O)cc(O)cc5O4)ccc3O[C@@H]2CO)ccc1O</smiles><smiles>COc1cc([C@H]2Oc3cc([C@@H]4Oc5cc(O)cc(O)c5C(=O)[C@H]4O)ccc3O[C@H]2CO)ccc1O</smiles><smiles>CCC1Oc2cc([C@@H]3Oc4cc(O)cc(Cl)c4C(=O)[C@H](O)C3CCO)ccc2O[C@@H]1c1ccc(O)c(OC)c1</smiles><smiles></smiles>

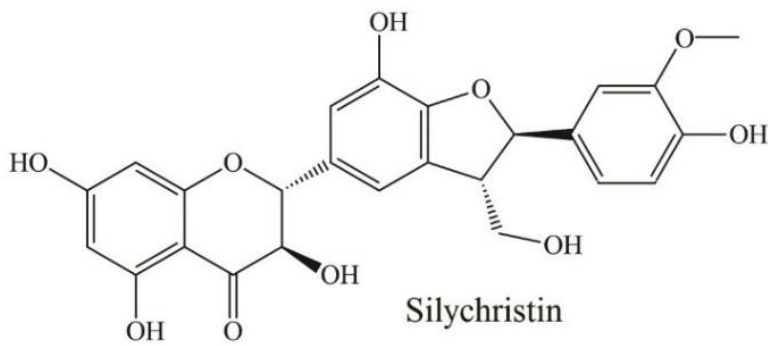

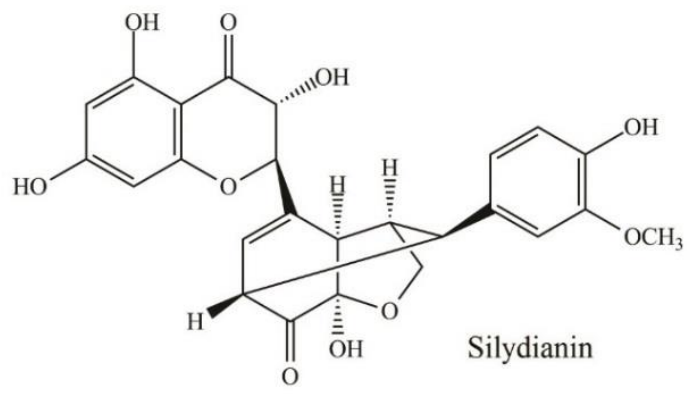

Fig. 1. Structural formulae of the silymarin major constituents

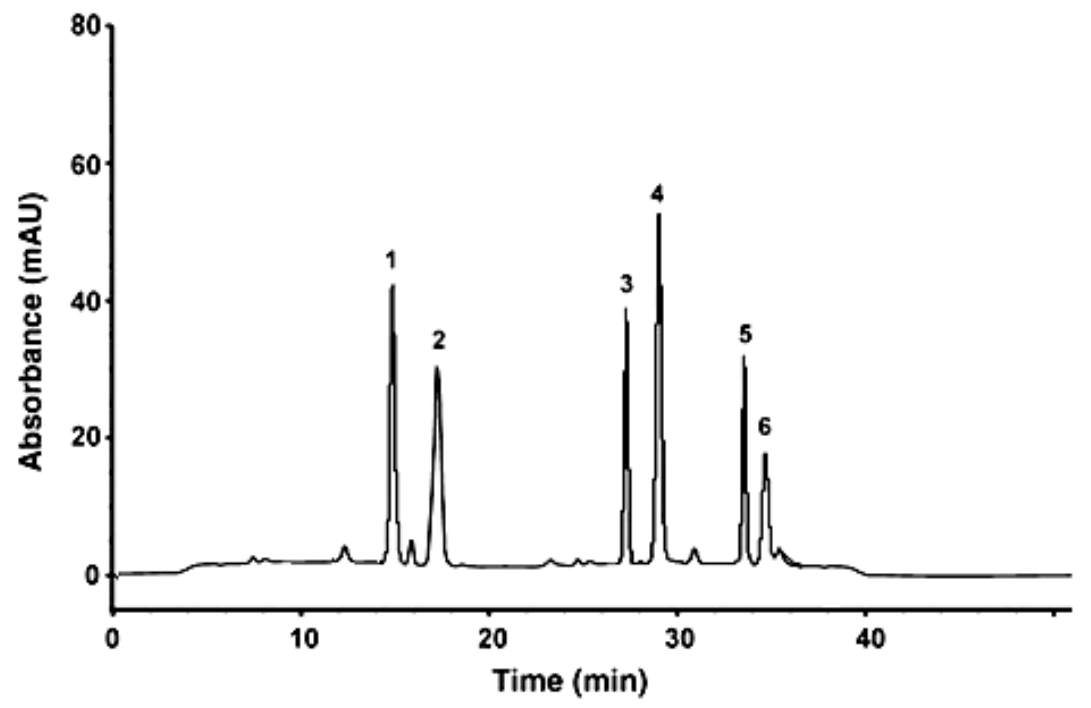

Fig. 2. Chromatograms of silymarin Peaks. (1) Silychristin, (2) Silydianin, (3) Silybin A, (4) Silybin B, (5) Isosilybin A, (6) Isosilybin B 
while the control group $(n=30)$ received placebo. The conventional oral hypoglycemic agent (metformin and glibenclamide) therapy in both groups continued. The results indicated a significant decrease in HbA1c levels from 9.81 to 8.25 at the end of the study in the case group but it increased from 9.83 to 10.21 in the placebotreated group. In the silymarin treated group, the fasting blood glucose $196 \mathrm{mg} / \mathrm{dL}, 2$ hour postprandial glucose $268 \mathrm{mg} / \mathrm{dL}$, total cholesterol $211 \mathrm{mg} / \mathrm{dL}$, and LDL cholesterol 129 $\mathrm{mg} / \mathrm{dL}$ were decreased significantly to 160 $\mathrm{mg} / \mathrm{dL}, 218 \mathrm{mg} / \mathrm{dL}, 193 \mathrm{mg} / \mathrm{dL}$ and 107mg/dL respectively. In the placebo-treated groups, there was no significant change in any blood parameters after 2-months as compared to the beginning of the study.

In the fourth study [28], the effects of silymarin on insulin resistance and blood lipid profile in the first-degree relatives of type 2 diabetic patients were evaluated. This study was carried out on 60 people with body mass index above $25 \mathrm{~kg} / \mathrm{m}^{2}$ and blood $\mathrm{HbA1c}$ and glucose levels were evaluated for 12 weeks in a randomized placebo control clinical trial study. The patients in the silymarin group received two $140 \mathrm{mg}$ capsules of silymarin daily and the placebo group took $140 \mathrm{mg}$ placebo capsules similarly for 12 weeks. The results demonstrated that in the case group, insulin resistance and serum insulin levels were reduced significantly $(\mathrm{P}<0.05)$ compared with the beginning of the study as well as the placebo group.

In the fifth study [17], silymarin as an adjunct to glibenclamide was tested for antihyperglycemic effect and body mass index in type 2 diabetes. Using a randomized, double-blind, placebocontrolled design, 59 type 2 diabetic patients with poor glycemic control, were treated with 200 $\mathrm{mg}$ /day for 120 days. In this study, silymarin treatment significantly reduced both fasting and postprandial plasma glucose, $\mathrm{HbA} 1 \mathrm{c}$ and decreased body mass index after 120 days. The author concluded that the anti-hyperglycemic effect of silymarin may be related to increased insulin sensitivity in peripheral tissues.

In the sixth study, the Ebrahimpour Koujana S. et al. [29], conducted a randomized, triple-blind, placebo-controlled clinical trial to find out the effects of silymarin on antioxidant status and hsCRP in 40 patients with type 2 diabetes mellitus. The patients received $140 \mathrm{mg}$ silymarin $(\mathrm{n}=20)$ seed extract, thrice daily and those in the other group received placebo at the same intervals for 45 days. The result indicated that silymarin supplementation improves some antioxidant indices such as superoxide dismutase, glutathione peroxidase, total antioxidant capacity and decrease hs-CRP levels in diabetic patients.

In another randomized placebo-controlled clinical trial Velussi et al. reported that administration of $600 \mathrm{mg}$ silymarin per day to cirrhotic diabetic patients improved hyperglycemia, hyperinsulinemia, exogenous insulin need and malondialdehyde levels [30].

Furthermore, in the study conducted by Khalili et al. [31], the anti-hyperglycemic effects of silymarin $(500 \mathrm{mg})$ mixed with nettle extract $(500 \mathrm{mg})$ and boswellia gum resin $(500 \mathrm{mg})$, at the dose of 1500 $\mathrm{mg}$ in three divided doses daily were evaluated in patients with type 2 diabetes mellitus. Sixty patients were diagnosed as type 2 diabetes with fasting blood glucose levels ranging from 150 to $180 \mathrm{mg} / \mathrm{dL}$, glycosylated hemoglobin levels from $7.5 \%$ to $8.5 \%$, receiving oral anti-hyperglycemic drugs, were allocated to receive the mixed herbal formulation or placebo for 90 days in a doubleblind randomized placebo-controlled clinical trial. The mean serum fasting blood glucose, glycosylated hemoglobin, and triglyceride in the herbal drug group decreased significantly compared with the placebo group's values in 3 months after the intervention. The characteristics of 
studies regarding effects of silymarin in treatments of diabetes included in this review are summarized in Table 1.

\subsection{Fatty liver clinical studies}

Non-alcoholic fatty liver disease (NAFLD) is a prevalent metabolic disorder causing macro vesicular fat deposition $\geq 5 \%$ in hepatocytes without any other pathological conditions with degeneration of hepatocytes like viral hepatitis and alcohol consumption. NAFLD doesn't usually demonstrate any clinical symptoms therefore, in most cases it remains undiagnosed for a long time before it is accidentally diagnosed through routine liver tests or becomes clinically evident after progression of advanced liver diseases [32].

Prevalence of NAFLD has globally increased to $25 \%$ along with obesity, type 2 diabetes mellitus, dyslipidemia, and metabolic syndrome [33]. The Middle East and South America share the highest and Africans experience the lowest rate [34]. Nowadays, NAFLD is the second main cause of cirrhosis and hepatocellular carcinoma and it is predicted that it will become the most frequent indication of liver transplantation by 2020 [35].

NAFLD pathogenesis is associated with a bunch of risk factors. Insulin resistance is highly associated with fat accumulation in hepatocytes [36]. Moreover, the prevalence of NAFLD in T2DM patients is over $76 \%$ and beta-cells dysfunction in obesity may play an important role in the development of this phenomenon [37, 38]. Despite the growing data about fatty liver pathogenesis and morbidity, major concerns have been focused on the lack of decisive and approved pharmacological interventions in order to decrease the disease progression and improve its treatment.
Several studies have indicated the clinical efficacy of herbal remedies in the improvement of some NAFLD factors including inflammation, metabolic risk factors, insulin resistance and oxidative stress [39].

The beneficial effects of silymarin or its main constituent silybin in treatment of the liver disease have previously been reviewed [13]. In a clinical trial conducted on non-alcoholic fatty liver disease, Wah Kheong et al. 2017, reported that, treatment with silymarin $700 \mathrm{mg} 3$ times a day for 48 weeks reduced liver fibrosis [40]. In three different studies [41-43] treatment of NAFLD patients with silymarin $280 \mathrm{mg} /$ day for 6 months, $280 \mathrm{mg} /$ day for 3 months and $210 \mathrm{mg} /$ day for 8 weeks improved hepatic enzymes abnormalities compared with placebo. In another clinical study Hajiagamohammadi et al. claimed that treatment with silymarin $140 \mathrm{mg} / \mathrm{d}$ for NAFLD patients significantly reduced liver enzyme levels in comparison to pioglitazone $15 \mathrm{mg} / \mathrm{d}$ or metformin $500 \mathrm{mg} / \mathrm{d}$ [44]. In another study, Aller et al. [45], reported similar beneficial effects of silymarin in daily doses of $1080.6 \mathrm{mg}$ plus vitamin $\mathrm{E} 72 \mathrm{mg}$ for three months in NAFLD patients. Han et al, reported that silymarin $210 \mathrm{mg} / \mathrm{d}$ for 12 weeks in combination with simvastatin had a better impact on non-alcoholic fatty liver and reduced serum transaminase, triglycerides and total cholesterol [46]. Loguercio et al., in a pilot clinical trial study, reported that silybin conjugated with phospholipids plus vitamin $E$ treatment of nonalcoholic fatty liver disease patients ameliorated liver steatosis, even though, the addition of vitamin E may induce synergistic effects [47]. One other study revealed that 138 fatty liver patients were subjected to a 
Table 1. Characteristics of studies (silymarin in treatment of diabetes) included in this review.

\begin{tabular}{|c|c|c|c|c|c|c|}
\hline Study & $\begin{array}{l}\text { Type of } \\
\text { study }\end{array}$ & $\begin{array}{c}\text { Study } \\
\text { populatio } \\
\text { n } \\
\end{array}$ & $\begin{array}{l}\text { Sample size } \\
\text { (group) }\end{array}$ & $\begin{array}{c}\text { Treatment } \\
\text { daily dosage }\end{array}$ & $\begin{array}{c}\text { Treatment } \\
\text { duration }\end{array}$ & $\begin{array}{c}\text { Outcome } \\
\text { measurements }\end{array}$ \\
\hline $\begin{array}{l}\text { Huseini et al. } \\
2006 \text { Iran } \\
\text { [25] }\end{array}$ & $\begin{array}{c}\text { rd-b } \\
\text { placebo- } \\
\text { controlled }\end{array}$ & $\begin{array}{l}51 \text { T2DP } \\
\text { under } \\
\text { Conv. } \\
\text { therapy }\end{array}$ & $\begin{array}{c}26 \text { patients in } \\
\text { silymarin } \\
\text { and } 25 \text { in placebo } \\
\text { groups }\end{array}$ & $\begin{array}{l}\text { silymarin } \\
200 \mathrm{mg} / \mathrm{tid}\end{array}$ & 4 months & $\begin{array}{l}\text { FBS, HbA1c, } \\
\text { lipid profile, liver } \\
\text { enzymes }\end{array}$ \\
\hline $\begin{array}{c}\text { Fallah } \\
\text { Huseini et al. } \\
2005[26]\end{array}$ & $\begin{array}{c}\text { rd-b } \\
\text { placebo- } \\
\text { controlled }\end{array}$ & $\begin{array}{l}60 \text { T2DP } \\
\text { under } \\
\text { Conv. } \\
\text { therapy }\end{array}$ & $\begin{array}{l}30 \text { patients in } \\
\text { each group }\end{array}$ & $\begin{array}{l}\text { silymarin } \\
250 \mathrm{mg} / \mathrm{tid}\end{array}$ & 4 months & $\begin{array}{l}\text { FBS, HbA1c, } \\
\text { liver enzymes }\end{array}$ \\
\hline $\begin{array}{c}\text { Ramezani et } \\
\text { al. Iran } 2008 \\
\text { [27] }\end{array}$ & $\begin{array}{c}\text { rd-b } \\
\text { placebo- } \\
\text { controlled }\end{array}$ & $\begin{array}{l}60 \text { T2DP } \\
\text { candidate } \\
\text { for insulin } \\
\text { therapy }\end{array}$ & $\begin{array}{l}30 \text { patients in } \\
\text { each group }\end{array}$ & $\begin{array}{l}\text { silymarin } \\
200 \mathrm{mg} / \mathrm{tid}\end{array}$ & 2 months & $\begin{array}{l}\text { FBS, HbAlc, } \\
\text { lipid profile, } \\
\text { creatinine, liver } \\
\text { enzymes }\end{array}$ \\
\hline $\begin{array}{c}\text { Mohammadi } \\
\text { et al. } 2013 \\
{[28]}\end{array}$ & $\begin{array}{c}\text { rd-b } \\
\text { placebo- } \\
\text { controlled }\end{array}$ & $\begin{array}{l}60 \text { first- } \\
\text { degree } \\
\text { relatives of } \\
\text { T2DP }\end{array}$ & $\begin{array}{l}30 \text { patients in } \\
\text { each group }\end{array}$ & $\begin{array}{l}\text { silymarin } \\
140 \mathrm{mg} / \mathrm{bid}\end{array}$ & 12 weeks & $\begin{array}{l}\text { FBG, HbA1c, } \\
\text { PPG lipid profile, } \\
\text { insulin, }\end{array}$ \\
\hline $\begin{array}{l}\text { Ebrahimpour } \\
\text { Koujan et al. } \\
2015 \text { [29] }\end{array}$ & $\begin{array}{c}\text { rt-b } \\
\text { placebo- } \\
\text { controlled }\end{array}$ & $\begin{array}{l}40 \text { T2DP } \\
\text { under } \\
\text { Conv. } \\
\text { therapy } \\
\end{array}$ & $\begin{array}{l}20 \text { patients in } \\
\text { each group }\end{array}$ & $\begin{array}{l}\text { silymarin } \\
140 \mathrm{mg} / \mathrm{tid}\end{array}$ & 45 days & $\begin{array}{l}\text { FBG, antioxidant } \\
\text { indices, hs-CRP }\end{array}$ \\
\hline $\begin{array}{c}\text { Hussain } 2007 \\
{[17]}\end{array}$ & $\begin{array}{c}\text { rd-b } \\
\text { placebo- } \\
\text { controlled }\end{array}$ & $\begin{array}{l}59 \text { T2DP } \\
\text { under } \\
\text { Gly. } \\
\text { therapy } \\
\end{array}$ & $\begin{array}{c}30 \text { patients in } \\
\text { silymarin } \\
\text { and } 29 \text { in placebo } \\
\text { groups }\end{array}$ & $\begin{array}{l}\text { silymarin } \\
200 \mathrm{mg} / \text { day }\end{array}$ & 4 months & $\begin{array}{c}\text { FBS, HbA1c, } \\
\text { BMI }\end{array}$ \\
\hline $\begin{array}{c}\text { Velussi et al. } \\
1997 \text { [30] }\end{array}$ & $\begin{array}{c}\text { rd-b } \\
\text { placebo- } \\
\text { controlled }\end{array}$ & $\begin{array}{c}\text { ITD } \\
\text { alcoholic } \\
\text { cirrhosis } \\
\text { patients }\end{array}$ & $\begin{array}{l}30 \text { patients in } \\
\text { each group }\end{array}$ & $\begin{array}{l}\text { silymarin } \\
600 \mathrm{mg} / \text { day }\end{array}$ & 12 months & $\begin{array}{l}\text { FBS, insulin, } \\
\text { HbAlc MDA, } \\
\text { insulin need }\end{array}$ \\
\hline $\begin{array}{l}\text { Khalili et } \\
\text { al.2017 [31] }\end{array}$ & $\begin{array}{c}\text { rd-b } \\
\text { placebo- } \\
\text { controlled }\end{array}$ & $\begin{array}{l}60 \text { T2DP } \\
\text { under } \\
\text { Conv. } \\
\text { therapy }\end{array}$ & $\begin{array}{l}30 \text { patients in } \\
\text { each group }\end{array}$ & $\begin{array}{l}\text { silymarin, } \\
\text { nettle, b. gum } \\
500 \mathrm{mg} \text { each }\end{array}$ & 3 months & $\begin{array}{l}\text { FBS, HbA1c, } \\
\text { lipid profile liver } \\
\text { enzymes }\end{array}$ \\
\hline
\end{tabular}

Type 2 diabetic patients (T2DP), body mass index (BMI), Fasting blood glucose (FBS), postprandial glucose (PPG), glibenclamide (Gly), randomized double-blind (rd-b), randomized triple-blind (rt-b), Insulin treated diabetic (ITD), boswellia gum (b. gum), high-sensitivity C-reactive protein (hs-CRP), conventional (Conv.), malondialdehyde (MDA)

multicenter clinical trial and received either placebo or silybin combination with phosphatidylcholine and vitamin $\mathrm{E}$ for 12 months. Results showed a significant improvement in serum liver enzymes, homeostasis model of insulin resistance, and liver histology [48]. Besides, in another study, silybin- vitamin e-phospholipid complex ameliorated aminotransferase, and non-invasive NAFLD index [49]. The characteristics of studies regarding effects of silymarin in treatment of fatty liver disease included in the review are summarized in Table 2. 
Table 2. Characteristics of studies (silymarin in treatment of fatty liver disease) included in this review.

\begin{tabular}{|c|c|c|c|c|c|c|}
\hline Study & $\begin{array}{l}\text { Type of } \\
\text { study }\end{array}$ & $\begin{array}{c}\text { Study } \\
\text { populatio } \\
\text { n }\end{array}$ & $\begin{array}{l}\text { Sample } \\
\text { size } \\
\text { (group) }\end{array}$ & $\begin{array}{l}\text { Treatment } \\
\text { dosage }\end{array}$ & $\begin{array}{c}\text { Treatment } \\
\text { duration }\end{array}$ & $\begin{array}{c}\text { Outcome } \\
\text { measurements }\end{array}$ \\
\hline $\begin{array}{l}\text { Wah Kheong } \\
\text { et al. } 2017 \\
{[40]}\end{array}$ & $\begin{array}{l}\text { placebo- } \\
\text { controlled } \\
\text { trial }\end{array}$ & $\begin{array}{l}99 \text { NAFLD } \\
\text { patients }\end{array}$ & $\begin{array}{l}49 \text { patients } \\
\text { in silymarin } \\
\text { and } 50 \text { in } \\
\text { placebo }\end{array}$ & silymarin $700 \mathrm{mg} / \mathrm{tid}$ & $48 \mathrm{x}$ & $\begin{array}{l}\text { FBS, fibrosis, } \\
\text { lipid profile, } \\
\text { liver enzymes }\end{array}$ \\
\hline $\begin{array}{l}\text { Hashemi et } \\
\text { al. } 2009 \text { [41] }\end{array}$ & $\begin{array}{l}\text { placebo- } \\
\text { controlled } \\
\text { trial }\end{array}$ & $\begin{array}{l}100 \text { NASH } \\
\text { patients }\end{array}$ & $\begin{array}{l}50 \text { patients } \\
\text { in each } \\
2 \text { groups }\end{array}$ & sily & & $\begin{array}{l}\text { GGT, FBS, lipid } \\
\text { profile, liver } \\
\text { enzymes }\end{array}$ \\
\hline $\begin{array}{l}\text { Masoodi et } \\
\text { al. } 2013 \text { [42] }\end{array}$ & $\begin{array}{l}\text { placebo- } \\
\text { controlled } \\
\text { trial } \\
\end{array}$ & $\begin{array}{l}100 \text { NASH } \\
\text { patients }\end{array}$ & $\begin{array}{l}50 \text { patients } \\
\text { in each } \\
\text { group }\end{array}$ & sily & $3 n$ & $\begin{array}{l}\text { liver enzymes, } \\
\text { BMI }\end{array}$ \\
\hline $\begin{array}{l}\text { Solhi et al. } \\
2014 \text { [43] }\end{array}$ & $\begin{array}{l}\text { placebo- } \\
\text { controlled } \\
\text { trial }\end{array}$ & $\begin{array}{l}64 \text { NASH } \\
\text { patients }\end{array}$ & $\begin{array}{l}33 \text { patients } \\
\text { in silymarin } \\
\text { and } 31 \text { in } \\
\text { placebo }\end{array}$ & silymarin $70 \mathrm{mg} / \mathrm{tid}$ & $8 \mathrm{w}$ & $\begin{array}{l}\text { abdominal } \\
\text { sonography, } \\
\text { liver enzymes, } \\
\text { BMI }\end{array}$ \\
\hline $\begin{array}{l}\text { Hajiagha- } \\
\text { mohammadi } \\
\text { et al. } 2012 \\
{[44]}\end{array}$ & $\begin{array}{l}\text { standard } \\
\text { drug } \\
\text { controlled } \\
\text { trial }\end{array}$ & $\begin{array}{l}66 \text { NAFLD } \\
\text { patients }\end{array}$ & $\begin{array}{l}22 \text { patients } \\
\text { in each } 3 \\
\text { groups }\end{array}$ & $\begin{array}{l}\text { 1-silymarin } 140 \mathrm{mg} / \mathrm{d} \\
\text { 2-metformin } 500 \mathrm{mg} / \mathrm{d} \\
\text { 3-pioglitazone } 15 \mathrm{mg} / \mathrm{d}\end{array}$ & $8 v$ & $\begin{array}{l}\text { FBS, insulin, } \\
\text { lipid profile, } \\
\text { BMI, AST, ALT }\end{array}$ \\
\hline $\begin{array}{l}\text { Aller et al. } \\
2015 \text { [45] }\end{array}$ & $\begin{array}{l}\text { placebo- } \\
\text { controlled } \\
\text { trial }\end{array}$ & $\begin{array}{l}36 \text { NAFLD } \\
\text { patients }\end{array}$ & $\begin{array}{l}18 \text { patients } \\
\text { in each } 2 \\
\text { groups }\end{array}$ & $\begin{array}{l}\text { silymarin } 540.3 \mathrm{mg} \\
+ \text { vitamin E } 36 \mathrm{mg} / \mathrm{bid}\end{array}$ & ths & $\begin{array}{l}\text { FBS, insulin, } \\
\text { liver enzymes, } \\
\text { fatty liver index, } \\
\text { fibrosis }\end{array}$ \\
\hline $\begin{array}{l}\text { Han et al. } \\
2011[46]\end{array}$ & $\begin{array}{l}\text { Vitamine } \mathrm{E} \\
\text { controlled } \\
\text { trial }\end{array}$ & $70 \mathrm{NASH}$ & $\begin{array}{l}35 \text { patients } \\
\text { in each } 2 \\
\text { groups }\end{array}$ & $\begin{array}{l}\text { 1-silymarin } 70 \mathrm{mg} \\
\text { + simvastatin } 10 \mathrm{mg} / \mathrm{tid} \\
\text { 2- vitamin E } 36 \mathrm{mg} / \mathrm{tid}\end{array}$ & & $\begin{array}{l}\text { liver enzymes, } \\
\text { lipid profile }\end{array}$ \\
\hline $\begin{array}{l}\text { Loguercio et } \\
\text { al. } 2007 \text { [47] }\end{array}$ & $\begin{array}{l}\text { systematic } \\
\text { random } \\
\text { sampling }\end{array}$ & $\begin{array}{l}85 \text { NAFLD } \\
\text { patients }\end{array}$ & $\begin{array}{l}59 \text { patients } \\
\text { in silybin } \\
\text { and } 26 \text { in } \\
\text { placebo }\end{array}$ & $\begin{array}{l}\text { 1-silybin } 94 \mathrm{mg} \\
+\mathrm{PC} 194 \mathrm{mg} / \mathrm{qid} \\
\text { 2-vitamin E } 89.28 \\
\mathrm{mg} / \mathrm{tid}\end{array}$ & 12 & $\begin{array}{l}\text { liver steatosis, } \\
\text { liver enzyme, } \\
\text { insulin, fibrosis }\end{array}$ \\
\hline $\begin{array}{l}\text { Loguercio et } \\
\text { al. } 2012 \text { [48] }\end{array}$ & $\begin{array}{l}\text { Phase III, } \\
\text { placebo- } \\
\text { controlled } \\
\text { trial }\end{array}$ & $\begin{array}{l}138 \\
\text { NAFLD } \\
\text { patients }\end{array}$ & $\begin{array}{l}69 \text { patients } \\
\text { in silybin } \\
\text { and } 69 \text { in } \\
\text { placebo }\end{array}$ & $\begin{array}{l}\text { silybin } 94 \mathrm{mg}+\text { PC } 194 \\
\mathrm{mg} \\
+\quad \text { vitamin } \\
\mathrm{mg} / \mathrm{bid}\end{array}$ & 12 months & $\begin{array}{l}\text { liver enzymes, } \\
\text { liver steatosis, } \\
\text { quality of life }\end{array}$ \\
\hline $\begin{array}{l}\text { Federico et } \\
\text { al. } 2006 \text { [39] }\end{array}$ & $\begin{array}{l}\text { systematic } \\
\text { random } \\
\text { sampling }\end{array}$ & $\begin{array}{l}85 \text { NAFLD } \\
\text { patients }\end{array}$ & $\begin{array}{l}53 \text { patients } \\
\text { in silybin } \\
\text { and } 32 \text { in } \\
\text { placebo }\end{array}$ & $\begin{array}{l}\text { silybin } 94 \mathrm{mg}+194 \mathrm{mg} \\
\text { PC } \\
\text { + vitamin E } 90 \mathrm{mg} / \mathrm{qid}\end{array}$ & 12 months & $\begin{array}{l}\text { FBS, liver } \\
\text { enzymes, liver } \\
\text { US, insulin } \\
\text { resistance }\end{array}$ \\
\hline
\end{tabular}

Phosphatidylcholine (PC), two times a day (bid), three times a day (tid), four times a day (qid) gamma-glutamyl trans peptidase (GGT), ultra-sonographic (US), non-alcoholic fatty liver disease (NAFLD), non-alcoholic steatohepatitis (NASH) 
The pathogenesis and progression of fatty liver disease is poorly understood. It seems that that the accumulation of fat in liver cells is the first stage in the onset of the disease. This phenomenon along with some factors such as obesity, insulin resistance and oxidative stress can promote and enhance inflammation, cell injury, apoptosis, fibrinogenase's leading to the development of NAFLD [55-56]. Silymarin is a potent antioxidant, and it has been reported that it has anti-daiabetic, anti-inflamatory, anti- oxidative, anti-fibrogenic and hypolipidemic effects inducing beneficial therapeutic effects on chronic liver diseases [17-20], (Fig. 3). The available evidence indicates that sylimarin increases glutathione and superoxide dismutase in the liver. Glutathione increases the liver capacity for detoxification, superoxide dismutase and stimulates protein synthesis in the liver in favor of liver cell protection and regeneration [57-59].

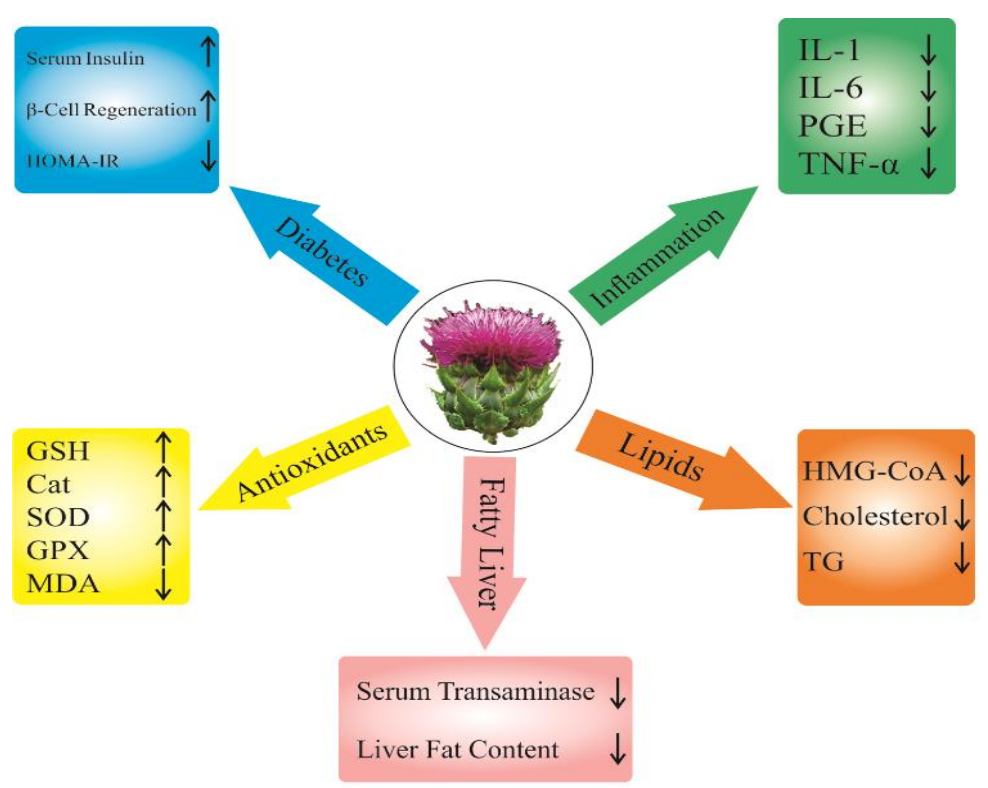

Fig. 3. Pharmacological effects of silymarin

\section{Discussion}

Since the last decade, silymarin has gradually been recognized as a promising complementary medication for diabetes. Silymarin treatment resulted in a statistically significant improvement in glycemic control in four studies compared with placebo [17, 25-27]. The studies showed that silymarin is an effective complementary agent for the treatment of type 2 diabetes. The diversity of results in these studies may be due to different patients, hyperglycemic condition as well as dosage differences of silymarin used and the duration of treatments. Besides, differences in baseline fasting blood glucose level may affect the results. A study carried out by Khalili N, et al. revealed that silymarin mixed with some other herbs for the treatment of type 2 diabetes decreased the mean serum fasting blood glucose, HbA1c compared with placebo [31]. Although, this survey indicated that silymarin may have an effective role concerning the control of diabetes, however, with regards to the usage of various 
herbals for the same purpose, its role was not perfectly evident. A study regarding the effects of silymarin on insulin resistance in first -degree relatives of T2DM carried out at our Diabetes Research Center illustrated that silymarin can bring about the decrease of insulin resistance. So, it is concluded that this herb may have a positive effect on diabetes control [28]. A research indicated that silymarin supplement improves antioxidant indices and reduces inflammatory biomarkers in T2DM [29]. Thus one may conclude that this drug can reduce diabetes implications. Patients with type 2 diabetes have a diversity of lipid abnormalities including high levels of LDL and triglyceride and low level of high density lipoprotein. Some of the studies also showed that silymarin not only has its positive effect on diabetes control but it can also reduce serum lipids [25, 27, 28]. In addition, type 2 diabetes usually accompanies NAFLD [6-7]. Several studies indicated that silymarin is highly effective in the reduction of hepatic enzymes in patients with NAFLD [26, 44-48]. Therefore, silymarin has been suggested as an attractive candidate for the prevention and treatment of diabetes and NAFLD. Silymarin is a safe drug and according to the European Commission's report, it has no serious side effects with approved therapeutic oral doses [21]. Doses in the ranges of 280 to $800 \mathrm{mg}$ of silymarin per day have been reported to be safe [60]. Although some adverse effects including plant hypersensitivity, laxative effect, digestive complications including heartburn as well as stomach upset and transient headache have been reported, it seems that there is no need for the discontinuation of the drug [61]. The consumption of silymarin is not contraindicated in pregnancy, lactation, and children, however, the side effects of long-term use of this herbal plant in pregnancy, breastfeeding and children have not been evaluated yet. It is also assumed that the safety of silymarin is based on its history of long-term usage. The efficacy of silymarin in the treatment of pruritus due to bile duct obstruction in pregnant women has been suggested. In addition, its consumption by pregnant women can prevent liver damage. It is necessary to administer it for pregnant women poisoned with Amanita fungi [62-64]. The mechanism of action of silymarin in diabetes and NAFLD has not fully been defined.

\section{Conclusion}

The current evidence suggest that silymarin may be clinically effective as an adjuvant with the standard therapy for the treatment of T2DM and NAFLD. However, given the insufficient available data, further large clinical trials are needed to confirm the beneficial effects of silymarin for the treatment of the above mentioned disorders.

\section{Author contributions}

Sayed Mohammad Mohammadi: data retrieval Saeed Kianbakht: writing and editing the article Shamsali Rezazadeh: data retrieval

Mojtaba Ziaee: data retrieval and writing the article

Hasan Fallah Huseini: data retrieval and writing the article

\section{Conflict of interest}

The authors declare that there is no conflict of interest. 


\section{References}

1. Ogurtsova K, da Rocha Fernandes JD, Huang Y, Linnenkamp U, Guariguata L, Cho NH, Cavan D, Shaw JE and Makaroff LE. IDF Diabetes Atlas: Global estimates for the prevalence of diabetes for 2015 and 2040. Diabetes Res. Clin. Pract. 2017; 128: 40-50.

2. Marjot T, Sbardella E, Moolla A, Hazlehurst J, Tan G, Ainsworth M, Cobbold J and Tomlinson J. Prevalence and severity of nonalcoholic fatty liver disease are underestimated in clinical practice: impact of a dedicated screening approach at a large university teaching hospital. Diabetic Medicine. 2018; 35 (1): 89-98.

3. Armstrong MJ, Hazlehurst JM, Parker R, Koushiappi E, Mann J and Khan S. Severe asymptomatic non-alcoholic fatty liver disease in routine diabetes care; a multi-disciplinary team approach to diagnosis and management. QJM. 2014; 107: 33-41.

4. Adams LA, Harmsen S, St Sauver JL, Charatcharoenwitthaya P, Enders FB and Therneau T. Nonalcoholic fatty liver disease increases risk of death among patients with diabetes: a community-based cohort study. Am. J. Gastroenterol. 2010; 105:1567-73.

5. Williamson RM, Price JF, Glancy S, Perry E, Nee LD and Hayes PC. Prevalence of and risk factors for hepatic steatosis and nonalcoholic Fatty liver disease in people with type 2 diabetes: the Edinburgh Type 2 Diabetes Study. Diabetes Care. 2011; 34: 1139-44.

6. Lomonaco R, Ortiz-Lopez C, Orsak B, Webb A, Hardies J, Darland C, Finch J, Gastaldelli A, Harrison $\mathrm{S}$ and Tio F. Effect of adipose tissue insulin resistance on metabolic parameters and liver histology in obese patients with nonalcoholic fatty liver disease. Hepatol. 2012; 55: 1389-1397.
7. Adams LA, Waters OR, Knuiman MW, Elliott RR and Olynyk JK. NAFLD as a risk factor for the development of diabetes and the metabolic syndrome: An Eleven-Year Follow-up Study. Am. J. Gastroenterol. 2009; 104: 861-7.

8. Tailleux A, Wouters K and Staels B. Roles of PPARs in NAFLD: potential therapeutic targets. Biochim. Biophys. Acta. 2012; 1821 (5): 809-18.

9. Philippe $\mathbf{J}$ and Raccah D. Treating type 2 diabetes: how safe are current therapeutic agents? Int. J. Clin. Pract. 2009; 63 (2): 321-332. 10. Clarke TC, Black LI, Stussman BJ, Barnes PM and Nahin RL. Trends in the use of complementary health approaches among adults: United States, 2002-2012. Natl. Health Stat Report. 2015; 79: 1-16.

11. Ekor M. The growing use of herbal medicines: issues relating to adverse reactions and challenges in monitoring safety. Front. Pharmacol. 2014; 4: 1-10.

12. Suksomboon N, Nalinee Poolsup N, Sukamai Boonkaew S, Chuthamanee $\mathrm{C}$ and Suthisisang C. Meta-analysis of the effect of herbal supplement on glycemic control in type 2 diabetes. J. Ethnopharmacol. 2011; 137: 13281333.

13. Jacobs BP, Dennehy C, Ramirez G, Sapp J and Lawrence VA. Milk thistle for the treatment of liver disease: a systematic review and metaanalysis. Am. J. Med. 2002; 113: 506-515.

14. Mozaffarian V. A dictionary of Iranian Plant Names (3ed.). Farhang Moaser Press. Iran. 2003, pp: 59-60.

15. Ghahreman A. Flora of Iran. Research Institute of Forests Rangelands, Tehran, Iran. 2000, Vol. 3, pp: 587.

16. Federico $A$, Dallio $M$ and Loguercio $C$. Silymarin/silybin and chronic liver disease: a marriage of many years. Molecules. 2017; 22 (2): 191. 
17. Hussain SA. Silymarin as an adjunct to glibenclamide therapy improves long-term and postprandial glycemic control and body mass index in type 2 diabetes. J. Med. Food. 2007; 10 (3): 543-7.

18. Trappoliere $M$, Caligiuri A, Schmid $M$, Bertolani C, Failli P, Vizzutti F, Novo E, di Manzano C, Marra F, Loguercio C and Pinzani M. Silybin, a component of sylimarin, exerts anti-inflammatory and anti-fibrogenic effects on human hepatic stellate cells. J. Hepatol. 2009; 50 (6): 1102-11.

19. Bosisio E, Benelli $C$ and Pirola O. Effect of the flavanolignans of Silybum marianum L. on lipid peroxidation in rat liver microsomes and freshly isolated hepatocytes. Pharmacol. Res. 1992; 25: 147-154.

20. Feher $J$ and Lengyel G. Silymarin in the treatment of chronic liver diseases: past and future. J. Clin. Exp. Med. 2009; 3 (3): 403-413.

21. Blumenthal $\mathrm{M}$. The complete commission German E monographs: Therapeutic guide to herbal medicines. American Botanical Council, Texas, USA, 1998.

22. Lee D Y-W and Liu Y. Molecular structure and stereochemistry of silybin A, silybin B, isosilybin A and isosilybin B. isolated from Silybum marianum (Milk Thistle). J. Nat. Prod. 2003; 66 (9): 1171-1174.

23. Varma PN and Talwar SK. Chemical investigations of Silybum marianum. Planta Med. 1980; 38: 377.

24. Brandon T, Gufford, Tyler N. Graf, Noemi D. Paguigan, Nicholas H. Oberlies and Mary F. Paine chemoenzymatic synthesis, characterization, and scale-up of milk thistle flavonolignan glucuronides. Drug Metab. Dispos. 2015; 43 (11): 1734-1743.

25. Fallah Huseini H, Larijani B, Heshmat R,
Fakhrzadeh H, Radjabipour B, Toliat T and Raza M. The efficacy of Silybum marianum L. Gaertn. (silymarin) in the treatment of type II diabetes: a randomized, double-blind, placebo-controlled, clinical trial. Phytoter. Res. 2006; 20 (12): 10361039.

26. Fallah Huseini H, Larijani B, Raajabipour B and Heshmat R. The effect of Silymarin on glycemic control of type II diabetes: A double blind randomized clinical trial. J. Med. Plants. 2005; 1 (13): 13-17.

27. Ramezani M, Azarabadi M, Abdi H, Baher $\mathrm{G}$ and Fallah Huseini H. The effects of Silybum marianum (L.) Gaertn.seed extract on glycemic control in type II diabetic patient's candidate for insulin therapy visiting endocrinology clinic in Baqiyatallah hospital in the years of 2006. $J$. Med. Plants. 2008; 2 (26): 79-84.

28. Mohammadi S, Fallah Huseini H, Afkhami Ardacani M, Salami M and Bolurani S. Effects of silymarin on insulin resistance and blood lipid profile in first-degree relatives of type 2 diabetic patients. J. Med. Plants. 2013; 2 (46): 170-176.

29. Ebrahimpour koujana S, Pourghassem Gargaria B, Mobasserib M, Valizadehc H and Asghari-Jafarabadi M. Effects of Silybum marianum (L.) Gaertn. (silymarin) extract supplementation on antioxidant status and hs-CRP in patients with type 2 diabetes mellitus: A randomized, triple-blind, placebo-controlled clinical trial. Phytomedicine. 2015; 22: 290-296.

30. Velussi M, Cernigoi AM, De Monte A, Dapas F, Caffau C and Zilli M. Long-term (12 months) treatment with an anti-oxidant drug (silymarin) is effective on hyperinsulinemia, exogenous insulin need and malondialdehyde levels in cirrhotic diabetic patients. J. Hepatol. 1997; 26: 871-879.

31. Khalili N, Fereydoonzadeh R, Mohtashami 
R, Mehrzadi S, Heydari M and Fallah Huseini H. Silymarin, Olibanum, and Nettle, a mixed herbal formulation in the treatment of type II diabetes: a randomized, double-blind, placebo-controlled, clinical trial. Evid.-based Complement. Alternat. Med. 2017; 22 (4): 603-608.

32. Buzzetti E, Pinzani $M$ and Tsochatzis $E A$. The multiple-hit pathogenesis of non-alcoholic fatty liver disease (NAFLD). Metab. Clin. Exp. 2016; 65 (8): 1038-1048.

33. Araújo A R, Rosso N, Bedogni G, Tiribelli $\mathrm{C}$ and Bellentani S. Global epidemiology of nonalcoholic fatty liver disease/non-alcoholic steatohepatitis: What we need in the future. Liver Int. 2018; 38 (S1): 47-51.

34. Younossi Z M, Koenig A B, Abdelatif D, Fazel Y, Henry L and Wymer M. Global epidemiology of nonalcoholic fatty liver diseasemeta-analytic assessment of prevalence, incidence, and outcomes. Hepatol. 2016; 64 (1): 73-84.

35. Marjot T, Sbardella E, Moolla A, Hazlehurst J, Tan G, Ainsworth M, Cobbold $J$ and Tomlinson J. Prevalence and severity of nonalcoholic fatty liver disease are underestimated in clinical practice: impact of a dedicated screening approach at a large university teaching hospital. Diabet. Med. 2018; 35 (1): 89-98.

36. Portillo-Sanchez P, Bril F, Maximos M, Lomonaco R, Biernacki D, Orsak B, Subbarayan S, Webb A, Hecht J and Cusi K. High prevalence of nonalcoholic fatty liver disease in patients with type 2 diabetes mellitus and normal plasma aminotransferase levels. J. Clin. Endocrinol. Metab. 2015; 100 (6): 2231-2238.

37. Wang L, Zhang J, Wang B, Zhang Y, Hong J, Zhang Y, Wang W and Gu W. New evidence for an association between liver enzymes and pancreatic islet $\beta$-cell dysfunction in young obese patients. Endocrine. 2013; 44(3): 688-95.

38. Pagano G, Pacini G, Musso G, Gambino R, Mecca F, Depetris N, Cassader M, David E, Cavallo-Perin $\mathrm{P}$ and Rizzetto $\mathrm{M}$. Nonalcoholic steatohepatitis, insulin resistance, and metabolic syndrome: further evidence for an etiologic association. Hepatol. 2002; 35: 367-372.

39. Yao H, Qiao YJ, Zhao YL, Tao XF, Xu LN, Yin LH, and Peng JY. Herbal medicines and nonalcoholic fatty liver disease. World $J$. Gastroenterol. 2016; 22 (30): 6890-6905.

40. Wah Kheong C, Nik Mustapha NR and Mahadeva S. A randomized trial of silymarin for the treatment of nonalcoholic steatohepatitis. Clin. Gastroenterol. Hepatol. 2017; 15 (12): 1940-1949. 41. Hashemi SJ, Hajiani E and Heydary SE. A placebo-controlled trial of silymarin in patients with nonalcoholic fatty liver disease. Hepat. Mon. 2009; 9 (4): 265-270.

42. Masoodi M, Rezadoost A, Panahian M and Vojdanian M. Effects of silymarin on reducing liver aminotransferases in patients with nonalcoholic fatty liver diseases. Govaresh. 2013; 18 (3): 181-185.

43. Solhi H, Ghahremani R, Kazemifar A M and Yazdi Z H. Silymarin in treatment of non-alcoholic steatohepatitis: A randomized clinical trial. Caspian J. Intern. Med. 2014; 5 (1): 9-12.

44. Hajiaghamohammadi AA, Ziaee A, Oveisi S and Masroor H. Effects of metformin, pioglitazone, and silymarin treatment on nonalcoholic Fatty liver disease: a randomized controlled pilot study. Hepat. Mon. 2012; 12 (8): 24-21.

45. Aller R, Izaola $\mathrm{O}$, Gómez $\mathrm{S}$, Tafur $\mathrm{C}$, González G, Berroa E, Mora N, González J and De Luis. Effect of silymarin plus vitamin $\mathrm{E}$ in patients with non-alcoholic fatty liver disease. A randomized clinical pilot study. Eur. Rev. Med. 
Pharmacol. Sci. 2015; 19 (16): 3118-3124.

46. Han M, Wen P, Wen J-b and XU L-f. Clinical effect of silymarin combined with simvastatin on patients with nonalcoholic steatohepatitis. Chin. J. Liver Dis. (Electronic Version). 2011; 3: 15-18. 47. Loguercio C, Federico A, Trappoliere M, Tuccillo C, De Sio I, Di Leva A, Niosi M, D'Auria M V, Capasso R and Blanco C D V. The effect of a silybin-vitamin e-phospholipid complex on nonalcoholic fatty liver disease: a pilot study. Dig. Dis. Sci. 2007; 52 (9): $2387-$ 2395.

48. Loguercio $\mathrm{C}$, Andreone $\mathrm{P}$, Brisc $\mathrm{C}$, Brisc MC, Bugianesi E, Chiaramonte M, Cursaro C, Danila M, de Sio I and Floreani A. Silybin combined with phosphatidylcholine and vitamin $\mathrm{E}$ in patients with nonalcoholic fatty liver disease: a randomized controlled trial. Free Radic. Biol. Med. 2012; 52 (9): 1658-1665.

49. Federico A, Trappoliere M, Tuccillo C, de Sio I, Di Leva A and Del Vecchio Blanco C. A new silybin-vitamin E-phospholipid complex improves insulin resistance and liver damage in patients with non-alcoholic fatty liver disease: preliminary observations. Gut. 2006; 55: 901-902.

50. Yao J, Zhi M, Gao X, Hu P, Li C and Yang $X$. Effect and the probable mechanisms of silybinin in regulating insulin resistance in the liver of rats with non-alcoholic fatty liver. Braz. J. Med. Biol. Res. 2013; 46 (3): 270-277.

51. Malihi F, Hosseini-Tabatabaei A, Esmaily $\mathrm{H}$, Khorasani R, Baeeri $\mathrm{M}$ and Abdollahi $\mathrm{M}$. Improvement of inflammatory and toxic stress biomarkers by silymarin in a murine model of type one diabetes mellitus. Cent. Eur. J. Biol. 2009; 4 (3): 369-380.

52. Elmarakby A A and Sullivan J C. Relationship between oxidative stress and inflammatory cytokines in diabetic nephropathy.
Cardiovasc. Ther. 2012; 30 (1): 49-59.

53. Fallah Huseini $H$, Asghari $B$, Asgarpanah J, Eghbali Zarch $\mathrm{T}$ and Babai Zarch A. Investigation of $\alpha$-Amylase and $\alpha$-Glucosidases inhibitory effects of Silybum marianum (L. Gaertn) seed extract in vitro. J. Med. Plants. 2012; 1 (41): 239-247.

54. Sales $P$ M, Souza $P$ M, Simeoni L A, Magalhães $\mathrm{P} O$ and Silveira D. $\alpha$-Amylase inhibitors: a review of raw material and isolated compounds from plant source. J. Pharm. Pharm. Sci. 2012; 15 (1): 141-183.

55. Marchesini G, Bugianesi E, Forlani G, Cerrelli F, Lenzi M and Manini R. Nonalcoholic fatty liver, steatohepatitis and the metabolic syndrome. Hepatol. 2003; 37 (4): 917-23.

56. Petta S, Muratore $C$ and Craxi A. Nonalcoholic fatty liver disease pathogenesis: the present and the future. Dig. Liver Dis. 2009; 41 (9): 615-25.

57. Valenzuela A, Aspillaga M, Vial S and Guerra R. Selectivity of silymarin on the increase of the glutathione content in different tissues of the rat. Planta Medica. 1989; 55: 420-422.

58. Muzes $G$ and et.al. Effect of the bioflavonoid silymarin on the in vitro activity and expression of super oxide dismutase (SOD) enzyme. Acta. Physiol. Hung. 1991; 78: 3-9.

59. Kropácová $K$, Misúrová $E$ and Haková $H$. Protective and therapeutic effect of silymarin on the development of latent liver damage. Radiats. Biol. Radioecol. 1998; 38 (3): 411-5.

60. Kazazis C E, Evangelopoulos A A, Kollas A and Vallianou N G. The therapeutic potential of milk thistle in diabetes. Rev. Diabet. Stud. 2014; 11 (2): 167-74.

61. Greenlee H, Abascal K, Yarne E and Ladas E. Clinical applications of Silybum marianum in oncology. Integr. Cancer Ther. 2007; 6 (2): 158-165. 
62. Giannola C, Buogo F, Forestiere G, Scaffidi L, Ferrigno V and Scaffidi A. A two-center study on the effects of silymarin in pregnant women and adult patients with so-called minor hepatic insufficiency. Clin. Ter. 1985; 114: 129-135.

63. Reyes $H$. The spectrum of liver and gastrointestinal disease seen in cholestasis of pregnancy. Gastroenterol. Clin. North Am. 1992; 21: 905-21.

64. Schleufe P and Seidel C. Amanita poisoning during pregnancy. Anasthesiol Intensivmed Notfallmed Schmerzther. 2003; 38 (11): 716-718.

How to cite this article: Mohammadi SM, Kianbakht S, Rezazadeh Sh, Ziaee M, Fallah Huseini H. Clinical efficacy of Silybum marianum seed extract in treatment of type 2 diabetes mellitus and non-alcoholic fatty liver disease: a narrative review. Journal of Medicinal Plants 2020; 19(73): 12-26. doi: 10.29252/jmp.1.73.12 
فصلنامه كياهان دارويى

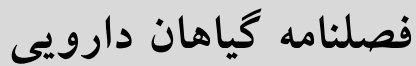

اثربخشى بالينى عصاره دانه گياه خار مريم (Silybum marianum) در درمان ديابت نوع r و بيمارى

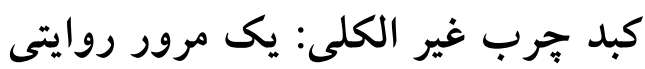

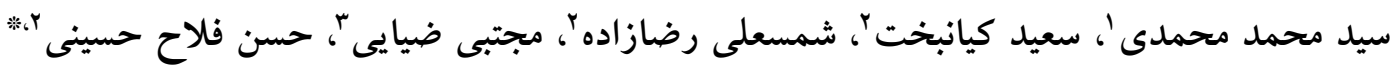

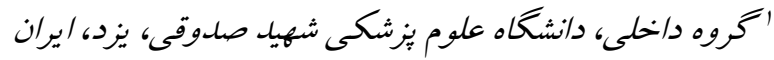

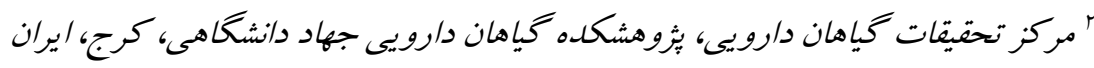

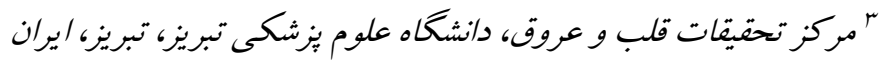
جكيده

مقدمه: جندين مطالعه بالينى به منظور بررسى اثرات درمانى احتمالى عصاره دانه كياه خار مريم

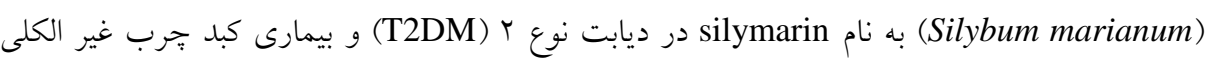
اطلاعات مقاله

\begin{tabular}{|c|c|}
\hline جكيده & اطلاعات مقاله \\
\hline 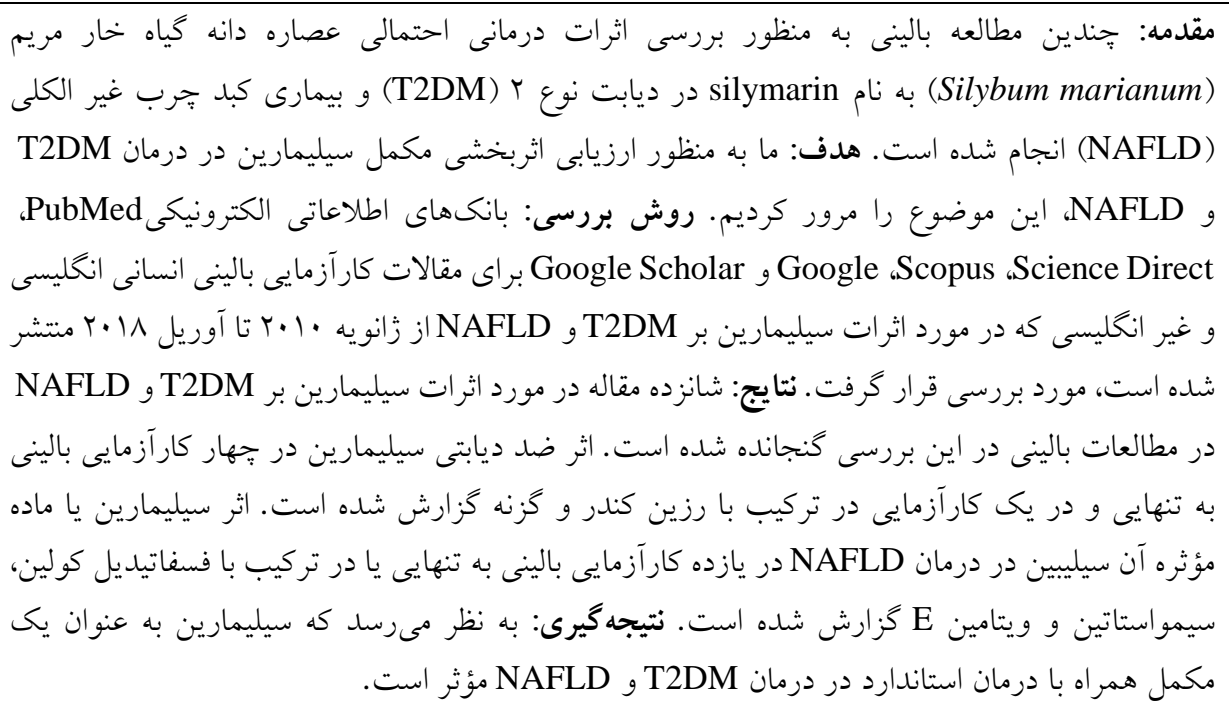 & كار كآرازگكان: \\
\hline
\end{tabular}

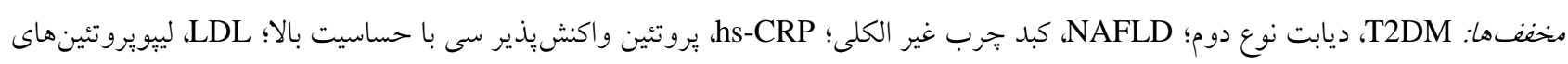
با خجالى كم؛ HbA1c، همو كلوبين كليكوزيله طويسنده مسؤول:

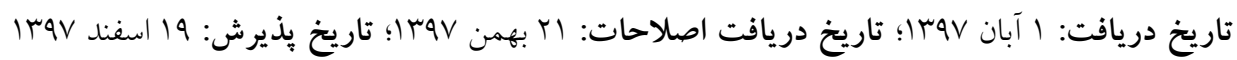
doi: 10.29252/jmp.1.73.12

(C) 2020. Open access. This article is distributed under the terms of the Creative Commons Attribution-NonCommercial 4.0 International License (https://creativecommons.org/licenses/by-nc/4.0/) 